\title{
MODEL PEMBELAJARAN PENDIDIKAN KARAKTER DI MI TARBIYATUS SHIBYAN JADUNG DUNGKEK SUMENEP
}

\author{
Hidayat \\ SMAN 1 Gapura, Sumenep \\ mila_mujahid@yahoo.co.id \\ Tri Sukitman \\ STKIP PGRI Sumenep \\ tri.sukitman@stkippgrisumenep.ac.id
}

\begin{abstract}
Abstrak
Pendidikan karakter merupakan pendidikan nilai, pendidikan budi pekerti, pendidikan moral, pendidikan watak yang bertujuan mengembangkan kemampuan seluruh warga sekolah untuk memberikan keputusan baik-buruk, keteladanan, memelihara apa yang baik dan mewujudkan kebaikan itu dalam kehidupan sehari- hari dengan sepenuh hati. Penelitian ini bertujuan: (1) mendeskripsikan model pembelajaran pendidikan karakter di MI Tarbiyatus Shibyan Jadung Dungkek Sumenep; (2) mengidentifikasi nilai-nilai pendidikan karakter di MI Tarbiyatus Shibyan Jadung Dungkek Sumenep; (3) menemukan faktor pendukung dan penghambat pendidikan karakter di MI Tarbiyatus Shibyan Jadung Dungkek Sumenep. Penelitian kualitatif ini dilaksanakan di MI Tarbiyatus Shibyan Jadung Dungkek Sumenep dengan subjek penelitian yaitu kepala sekolah, guru siswa dan orang tua siswa. Data dikumpulkan melalui wawancara, obeservasi, dokumentasi serta dianaliasis dengan menggunakan teknik analisis data yaitu pengumpulan data, pengorganisasian data, display data dan kesimpulan.
\end{abstract}

\section{Kata kunci: Model pembelajaran, karakter, madrasah ibtidaiyyah \\ Abstract}

Character education is value education, character education, moral education, character education which develops the ability to support schools, provide an example, improve what is good and realize what is in everyday life with all my heart. This research studies: (1) describes the character education learning model in MI Tarbiyatus Shibyan Jadung Dungkek Sumenep; (2) the values ??of character education in MI Tarbiyatus Shibyan Jadung Dungkek Sumenep; (3) finding supporting and inhibiting factors for character education in MI Tarbiyatus Shibyan Jadung Dungkek Sumenep. This qualitative research was conducted at MI Tarbiyatus Shibyan Jadung Dungkek Sumenep with research subjects namely the principal, teacher students and parents of students. Data is collected through interviews, observation, documentation and analysis using data analysis techniques, namely data collection, data organization, data display and conclusions.

Keywords: learning model, character, madrasah ibtidaiyyah

\section{Pendahuluan}

Pendidiakan saat ini masih memiliki nilai strategis dalam pembentukan karakter suatu bangsa terutama karakter peserta didik. Pembangunan karakter bangsa secara filosofis meruapakan sebuah kebutuhan asasi dalam berbangasa karena hanya bangsa yang memiliki karakter dan jatidiri yang kuat dan eksis. Jenjang pendidikan dasar merupakan fondasi awal untuk melangkah melanjutkan pendidikan. Bila penanaman karakter gagal dilakukan pada tahap usia pendidikan dasar, maka bisa dipastikan, karakter yang tertanam pada peserta didik kurang optimal. Pengembangan pendidikan berkaraktek bagi peserta didik harus diterapkan sungguh-sungguh karena kepribadian dan karakter yang kuat mempengaruhi masa depan bangsa. Anak usia madrasah ibtidaiyah merupakan masa kritis dalam pembentukan karakter. Menurut Freud, kegagalan dalam memberikan penanaman dan pembinaan kepribadian berkarakter pada anak. Dalam proses pembelajaran berbasis karakter meniscayakan pola pembinaan karakter secara komprehensif pada semua bidang studi yang diajarkan sia madrasah ibtidaiyah akan membentuk pribadi yang bermasalah pada saat dewasa.

Permasalahan karakter bangsa tersebut dilatarbelakangi oleh realita permasalahan kebangsaan yang berkembang saat ini, 
Hidayat, Tri Sukitman

seperti: disorientasi dan belum dihayatinya nilai-nilai Pancasila; keterbatasan perangkat kebijakan terpadu dalam mewujudkan nilai-nilai Pancasila; bergesernya nilai etika dalam kehidupan berbangsa dan bernegara; memudarnya kesadaran terhadap nilai-nilai budaya bangsa; ancaman disintegrasi bangsa; dan melemahnya kemandirian bangsa (Kemdiknas, 2011).

Pendidikan karakter di Indonesia menitikberatkan bukan hanya pada pemahaman anak didik secara konseptual dan kontekstual saja, namun juga diharapkan anak didik mampu berkreasi dan berinovasi secara tepat. Anak didik juga diharapkan memiliki rasa jujur, kritis, demokratis, rasa apresiasi yang tinggi dan nilai ketuhanan. Selain itu pendidikan juga dipercaya sebagai wadah yang dapat membangunkecerdasan peserta didik ke arah yang lebih baik. Untuk itulah, pemerintah menyadari perlunya pembentukan karakter mulai usia dini. Namun, pendidikan karakter yang paling tepat diterapkan secara menyeluruh ada pada usia jenjang pendidikan dasar, dimana usia jenjang pendidikan dasar merupakan usia emas dalam pembentukan karakter, watak, dan kepribadian seseorang.

Pendidikan karakter merupakan salah satu topik pendidikan yang saat ini menjadi sorotan pemerintah, guru, dosen dan masyarakat. Furqan dalam Abdul Majid \& Dian Andayani, 2013) menegaskan bahwa terdapat beberapa faktor penyebab rendahnya pendidikan karakter. Pertama, dalam sistem pendidikan yang kurang menekankan dalam pembentukan karakter, tetapi lebih menekankan kepada intelektual. Kedua, kondisi lingkungan (budaya dan sosial) yang kurang mendukung dalam pembangunan karakter yang baik. Pendidikan Karakter menurut Ratna Megawangi adalah sebuah usaha untuk mendidik anak-anak agar dapat mengambil keputusan dengan bijak dan mempraktikanya dalam kehidupan seharihari, sehingga mereka dapat memberikan kontribusi yang positif kepada lingkungannya. (Agus Wibowo, 2013).

Untuk memahami konsep ini pada pendidikan karakter secara komprehesif, dapat diperoleh dari beberapa pengertian dan komentar dari para ahli. Pendidikan karakter seringkali dikatakan sebagai nilai, norma, budi pekerti dan moral hal ini di sebabkan karena seringkali banyak dirumuskan dalam berbagai konsep yang berbeda-beda. Secara etimologis, kata "karakter" bisa berarti tabiat, sifat kejiwaan, akhlak atau budi pekerti yang membedakan seseorang dengan yang lain atau watak. (Tim Redaksi Tessaurus Bahasa Indonesia, 2008).

Menurut Doni Koesoema, (2007), orang yang berkarakter berarti orang yang memiliki watak, kepribadian, budi pekerti, atau akhlak. Dengan makna seperti ini, berarti karakter identik dengan kepribadian atau akhlak. Kepribadian merupakan ciri atau karakteristik atau sifat khas dari diri seseorang yang bersumber dari bentukanbentukan yang diterima dari lingkungan, misalnya keluarga pada masa kecil dan juga bawaan sejak lahir. Adapun secara terminologis, makna karakter yang dikemukakan oleh Thomas Lickona, menurutnya karakter adalah "a reliable inner disposition to respond to situations in a morally good way". Selanjutnya, menurut Lickona menambahkan, "character so conceived has three interrelated parts: moral knowing, moral feeling, and moral behavior"(Thomas Lickona, 1991).

Pendidikan karakter adalah sebuah sistem yang menanamkan nilai-nilai karakter pada peserta didik yang mengandung komponen-komponen pengetahuan, kesadaran individu, tekad, serta adanya kemauan dan tindakan untuk melaksanakan nilai-nilai baik Terhadap Tuhan Yang Maha Esa, diri sendiri, sesama manusia, lingkungan dan juga bangsa sehingga akan terwujud insan kamil ( Nurla Isna Ainullah, 2011)

Untuk membentuk karakter pada seorang individu harus dilakukan sedini mungkin, yakni dapat dimulai pada anak 
usia sekolah dasar. Karena pada jenjang sekolah dasar inilah adalah saat yang sangat tepat untuk memulai menanamkan karakter yang baik kepada siswa. Dalam penelitian yang telah dilakukan oleh (Oktarina \& et all, 2015) mengungkapkan bahwa elementary is the basic education system need to be planted the good character as a fundament (Sekolah dasar adalah sistem pendidikan dasar yang dibutuhkan untuk menanamkan karakter yang baik sebagai landasan). Hal ini juga senada dengan penelitian yang telah dilakukan oleh (Wijanarko, 2011) yang mengatakan bahwa penanaman karakter kepemimpinan sejak usia dini sangatlah penting agar kelak lahir calon-calon pemimpin bangsa yang baik, yang berwawasan dan berkemanusaiaan.

Oleh karena itu utuk membentuk karakter yang baik, anak membutuhkan model pembelajaran karater yang dibutuhkan dalam kehidupan sehari-harinya. Model pembelajaran karakter digunakan untuk mengembangkan potensi yang ada pada dirinya. Sebagaimana tercantum dalam Undang-Undang Republik Indonesia Nomor 20 Tahun 2001 Pasal 3 dinyatakan bahwa pendidikan nasional berfungsi mengambangkan kemampuan dan membentuk watak dan peradaban bangsa yang bermartabat dalam rangka mencerdaskan kehidupan bangsa, bertujuan untuk berkembangnya potensi peserta didik agar menjadi manusia yang beriman dan bertakwa kepada Tuhan Yang Maha Esa, berakhlak mulia, sehat berilmu, cakap, kreati, mandiri dan menjadi warga negara yang demokratis dan bertanggungjawab (Depdikbud, 2003).

Pembiasaan tersebut bukan hanya mengajarkan pengetahuan tentang hal-hal yang benar dan yang salah, akan tetapi juga mampu merasakan terhadap nilai yang baik dan tidak baik, serta bersedia melakukannya dari lingkup terkecil seperti keluarga sampai dengan cakupan yang lebih luas di masyarakat. Nilai-nilai tersebut perlu ditumbuhkembangkan peserta didik yang pada akhirnya akan menjadi cerminan hidup bangsa Indonesia.

Kementrian pendidikan nasional dalam rangka lebih memperkuat pelaksanaan pendidikan karakter pada satuan pendidikan telah mengiidentifikasi 18 nilai yang bersumber dari agama, Pancasila, budaya, dan tujuan pendidikan nasional, yaitu: (1) Religius, (2) Jujur, (3) Toleransi, (4) Disiplin, (5) Kerja keras, (6) Kreatif, (7) Mandiri, (8) Demokratis, (9) Rasa Ingin Tahu, (10) Semangat Kebangsaan, (11) Cinta Tanah Air, (12) Menghargai Prestasi, (13) Bersahabat/Komunikatif, (14) 11 Cinta Damai, (15) Gemar Membaca, (16) Peduli Lingkungan, (17) Peduli Sosial, (18) Tanggung jawab (Kemdiknas: 2011).

Berdasarkan fungsi dan tujuan pendidikan nasional, pendidikan di setiap jenjang, termasuk pendidikan dasar (MI/SD) harus diselenggarakan secara sistematis. Hal tersebut berkaitan dengan pembentukan karakter peserta didik sehingga mampu bersaing, beretika, bermoral, sopan santun dan berinteraksi dengan masyarakat. Langkah integrasi pembinaan pendidikan karakter pada setiap bidang studi yang diajarkan di sekolah menuntut adanya kompetensi para guru di samping adanya dukungan bahan ajar yang harus diorientasikan pada penanaman karakter.

Berdasarkan penelitian yang diterbitkan oleh Character Education Partnership, ternyata kesuksesan seseorang tidak ditentukan semata-mata oleh pengetahuan dan kemampuan teknis (hard skill) saja, tetapi lebih oleh kemampuan mengelola diri dan orang lain (soft skill). Penelitian ini mengungkapkan, kesuksesan hanya ditentukan sekitar $20 \%$ oleh hard skill dan sisanya $80 \%$ oleh soft skill. Bahkan orangorang tersukses di dunia bisa berhasil dikarenakan lebih banyak didukung kemampuan soft skill daripada hard skill. Hal ini mengisyaratkan bahwa mutu pendidikan karakter peserta didik sangat penting untuk ditingkatkan (Suyanto, 2009).

Dalam proses pembelajaran berbasis karakter meniscayakan pola pembinaan 
Hidayat, Tri Sukitman

karakter secara komprehensif pada semua bidang studi yang diajarkan Namun pada kenyataannya, metode pembelajaran yang dilakukan guru untuk membentuk karakter anak masih dikategorikan belum terlihat dapat menarik minat anak. Rata-rata usia anak Indonesia saat masuk sekolah dasar atau madarasah ibtidaiyah adalah berusia 6 tahun dan selesai pada usia 12 tahun, dimana pada rentang usia tersebut memiliki karakteristik yang berbeda dengan anakanak yang usianya lebih muda atau lebih tua di atasnya. la senang bermain, senang bergerak, senang bekerja dalam kelompok, dan senang merasakan atau melakukan sesuatu secara langsung (Wafiqni \& Latip, 2015). Oleh karena itu, sebagai seorang guru hendaknya harus mengembangkan pembelajaran yang mengandung unsur permainan, belajar dalam berkelompok, dan melibatkan siswa secara langsung dalam pembelajaran.

Secara teoretik guru harus memperhatikan dampak positif proses pembelajaran yang komprehensif karena sangat besar manfaatnya untuk jangka panjang. Kepemilikan proses pembelajaran komprehensif ini bisa diperoleh melalui proses pendidikan, pelatihan dan/atau workshop pendididkan karakter. Proses pembelajaran berbasis karakter akan berlangsung efektif ketika di dalamnya terdapat perencanaan pembelajaran yang memuat prosedur pembelajaran, kegiatan pembelajaran sebagai wujud dari perencanaan dan penilaian sebagai tolok ukur ketercapaian tujuan pembelajaran berbasis karakter.

Berdasakan hasil pengamatan dan pengalaman selama ini, siswa yang kurang terbuka apabila mengalami kesulitan dalam belajar baik kepada guru, teman maupun orang lain. Terutama terhadap siswa yang mempunyai kemampuan di bawah ratarata. Mereka takut bertanya meskipun sudah dipancing dengan pertanyaan yang merangsang daya fikir mereka. Siswa cenderung malas belajar, cepat menyerah atau putus asa. Hal ini tampak dari kuis atau tugas yang diberikan guru yang hasilnya tidak memuaskan bahkan kadang tidak dapat diselesaikan.

Siswa yang kurang aktif dalam kegiatan pembelajaran, siswa tampak bingung, acuh tak acuh, bahkan ada sebagian siswa yang sama sekali tidak memperhatikan penjelasan dari guru atau temannya, cepat putus asa pada saat dalam menyelesaikan tugas. Hal ini yang demikian dapat menunjukkan lunturnya atau memburuknya karakter atau kepribadian siswa baik di sekolah maupun di luar sekolah. Memburuknya karakter tersebut berimplikasi martabat bangsa Indonesia yang dinilai rendah oleh bangsa lain. Untuk membentuk karakter anak bukan hanya menjadi tanggung jawab guru agama, melainkan semua tenaga pendidik dan kependidikan bertanggung jawab terhadap proses pembentukan tersebut. Pendidik harus secara terpadu mengelola pembelajaran menuju pembentukan karakter anak, di antaranya dengan keterpaduan kurikulum pada tiap-tiap mata pelajaran.

Madrasah Ibtidaiyah Tarbiyatus Shibyan Jadung Dungkek ini merupakan salah satu lembaga pendidikan dasar yang secara spesifik mencanangkan dan menerapkan pendidikan karakter. Hal itu setidaknya terlihat dari tujuan yang hendak dicapai (visi misi madrasah) dan

berbagai kegiatan yang menunjangnya seperti melalui kegiatan pembiasaan dan ekstrakurikuler. Kegiatan pembiasaan yang dilakukan antara lain baca Surat Yasin tadarus al-Qur'an, apel pagi dan lain sebagainya. Kemudian kegiatan ekstrakurikuler berupa kegiatan-kegiatan pengembangan diri antara lain pramuka, drum band, qiro'ah, qasidah.

Madrasah Ibtidaiyah Negeri MI Tarbiyatus shibyan beralamat di Jalan Raya Dungkek Jadung Dungkek Sumenep Pada Madrasah ini pendidikan karakter implementasikan secara implisit terintegrasi dengan kegiatan belajar mengajar di kelas. Penelitian ini bertujuan: (1) mendeskripsikan model pembelajaran pendidikan karakter di MI Tarbiyatus 
Shibyan Jadung Dungkek Sumenep; (2) mengidentifikasi nilai-nilai pendidikan karakter di MI Tarbiyatus Shibyan Jadung Dungkek Sumenep.

\section{Metode Penelitian}

Penelitian ini merupakan penelitian kualitatif dengan pendekatan studi kasus. Penelitian ini dilaksanakan pada bulan Agustus 2018 sampai dengan Desember 2018 di MI Tarbiyatus Shibyan Jadung Dungkek Sumenep. Populasi dalam penelitian ini adalah seluruh siswa MI Tarbiyatus Shibyan. Sampel penelitian ini menghasilkan informasi data yang ditarik dan dikembangkan secara purposive sampling yaitu teknik penentan sampel dengan pertimbangan tertentu (Sugiyono, 2015). Penentuan Madrasah Ibtidaiyah sebagai sasaran penelitian dengan pertimbangan, bahwa MI merupakan jenjang pendidikan formal paling dasar yang di dalamnya masih terdapat usia anak-anak (golden age). Yang lebih mudah untuk diarahkan pada pembentukan karakter yang lebih baik

Teknik pengumpulan data yang digunakan yaitu observasi, wawancara, dan dokumentasi dan FGD. Observasi dalam penelitian ini digunakan untuk mengukur kegiatan pelaksanaan model pembelajaran pendidikan karakter di Madrasah Ibtidiyah Tarbiyatus Shibyan. Dalam kegiatan observasi, peneliti mengamati dan menilai aktivitas model peemblajaran yang dilakukan oleh guru. Sedangkan wawancara digunakan sebagai penguatan dari focus group discussion dan observasi. Dokumentasi dalam peneliti untuk melihat gambaran dari pelaksanaan penelitian. Focus Group Discussion di gunakan untuk mencari model pembelaranjaran karakter yang efektif bagi siswa. Berbagai data yang terhimpun kemudian dianalisis dengan kualitatif yang dikembangkan oleh Miles dan Huberman. Menurut Miles \& Huberman (1994) tahapan analisis data kualitatif adalah penghimpunan data, reduksi, display, dan kesimpulan.

\section{Hasil dan Pembahasan Model Pembelajaran Pendidikan Karakter di MI Tarbiyatus Shibyan}

Hasil penelitian menunjukakan bahwa $67 \%$ guru MI Tarbiyatus Shibyan memahami pembelajarab berbasis karater. Nilai ini menggambarkan bahwa guru $\mathrm{MI}$ memahami dengan cukup konsep pembelajaran berbasis karakter. Dalam penelitian ini ada tiga dimensi dalam pembelajaran berbasis karakter yaitu desain pembelajaran berbasis karakter, pendekatan pembelajaran berbasis karakter serta penilaian pembelajaran berbasis karakter. Model pembelajaran konstruktivisme dapat mengembangkan pengetahuan bagi peserta didik, melalui materi atau konsep yang dipelajari. Siswa melakukan sendiri kegiatan penelitian atau pengamatan langsung, menganalisis sesuai dengan materi yang dipelajari sehingga siswa dapat menyalurkan ide-ide baru sesuai dengan pengalaman dan mengaitkannya dengan dunia nyata untuk menemukan fakta yang sesuai dengan kajian teori dan menemukan makna dari apa yang dipelajarinya dan dapat bermanfaat bagi kehidupannya.

Pembelajaran merupakan proses interaktif dari kegiatan belajar dan mengajar. Perspektif ini mendasari proses pembelajaran yang berakhir pada terciptanya keseimbangan kegiatan yang dilakukan oleh pelajar dan pengajar. Pengajar berperan dalam merencanakan, melaksanakan dan mengevaluasi bahan pengajaran, memilih metode pengajaran, mengolah media pengajaran, menentukan indikator hasil belajar bahkan menetapkan karakter yang diharapkan. Pembelajar berperan aktif dalam mengeksplorasi, mengelaborasi dan mengkonfirmasi setiap kegiatan yang difasilitasi oleh pengajar (Siregar dan Hartini, 2010)

Model pembelajaran konstruktivisme dapat mengembangkan pengetahuan bagi peserta didik, melalui materi atau konsep yang dipelajari. Siswa melakukan sendiri langsung, menganalisis sesuai dengan materi yang dipelajari sehingga siswa 
Hidayat, Tri Sukitman

dapat menyalurkan ide-ide baru sesuai dengan pengalaman dan mengaitkannya dengan dunia nyata untuk menemukan fakta yang sesuai dengan kajian teori dan menemukan makna dari apa yang dipelajarinya dan

dapat bermanfaat bagi kehidupannya. Pembelajaran karakter dilaksanakan melalui proses belajar dengan setiap mteri pelajaran atau kegiatan yang dirancang khusus dan mengembangkan kemampuan dalam ranah kognitif, afektif, dan psikomotorik. Pembelajaran tersebut tidak selalu diperlukan suatu kegiatan belajar khusus untuk mengembangkan nilai-nilai pada pendidika karakter. Strategi pelaksanaan pendidikan karakter di satuan pendidikan merupakan suatu kesatuan dari program manajemen peningkatan mutu berbasis sekolah yang terimplementasi dalam pengembangan, pelaksanaan dan evaluasi kurikulum oleh setiap satuan pendidikan. Kemdiknas (2011) menyatakan bahwa agar pendidikan karakter dapat dilaksanakan secara optimal, pendidikan karakter diimplementasikan melalui langkahlangkah berikut: (a) Sosialisasi ke stakeholders (komite sekolah, masyarakat, lembaga-lembaga); dan Pengembangan dalam kegiatan sekolah diwujudkan melalui pembelajaran aktif dengan penilaian berbasis kelas disertai dengan program remediasi dan pengayaan. Pendidikan karakter atau ahlak mulia melalui sekolah merupakan usaha mulia yang terus ditekankan dan dikembangkan. Kalau kita berbicara tentang masa depan, sekolah tidak hanya bertanggungjawab dalam mencetak peserta didik yang unggul dalam ilmu pengetahuan dan teknologi, tetapi yang lebih penting adalah pembentukan jati diri, karakter dan kepribadian yang Islami.

Selain itu, hasil wawancara dengan guru pendamping diketahui bahwa pada pembelajaran tematik, pendidikan karakter lebih mudah dimasukkan karena tidak tergantung pada saat kapan dan pelajaran yang mana yang harus dimasuki pendidikan karakter. Siswa telah terbiasa dengan etika, dan peraturan/ kontrak belajar. Sehingga, mereka telah terbiasa dengan mana yang boleh dan tidak, dan mana yang baik dan yang tidak. Ketika ada temannya yang tidak mematuhi peraturan, atau misalnya tidak mau bekerjasama, maka siswa saling mengingatkan. Jadi lebih fleksibel. Kadang kita harus memperhatikan mood siswa juga, karena kadangkala siswa akan lebih belajar ketika pada titik tertentu mereka memutuskan sendiri apa yang akan mereka kerjakan untuk mempelajari sesuatu

\section{Nilai-nilai Pendidikan Karakter di MI Tarbiyatus Shibyan}

Pembentukan karakter adalah bagian integral dari orientasi pendidikan Islam. Tujuannya adalah membentuk kepribadian seseorang agar berperilaku jujur, baik, bertanggung jawab, menghormati dan menghargai orang lain, adil tidak diskriminatif, pekerja keras dan karakterkarakter unggul lainnya. Agama Islam, mempunyai dua istilah yang menunjukkan penekanan mendasar pada aspek pembentukan karakter dalam pendidikan: yakni ta'dib dan tarbiyyah. Ta'dib berarti usaha untuk menciptakan situasi yang mendukung dan mendorong anak didik untuk berperilaku baik dan sopan sesuai yang diharapkan. Sementara tarbiyyah berarti merawat potensi-potensi baik yang ada pada diri manusia agar tumbuh dan berkembang (Direktorat Pendidikan Madrasah: 2010)

Madrasah merupakan lembaga pendidikan Islam yang lebih modern, yang memadukan antara pendidikan pesantren dan sekolah, yang materinya mengintegrasikan agama dan pengetahuan umum. Madrasah sebagai lembaga pendidikan Islam berfungsi menghubungkan sistem lama dan sistem baru dengan jalan memper-tahankan nilainilai lama yang masih baik dan dapat dipertahankan dan mengambil sesuatu yang baru dalam ilmu, teknologi, dan ekonomi yang bermanfaat bagi kehidupan umat Islam, sedangkan isi kurikulum 
madrasah pada umumnya sama dengan pendidikan di pesantren ditambah dengan ilmuilmu umum. Dalam pelaksanaannya dengan meng gunakan pendekatan kontekstual, yaitu siswa diajak menghubungkan atau mengkaitkan materi yang dipelajari dengan dunia nyata, dan akhirnya diharapkan bahwa pengetahuan yang dimiliki dapat diterapkan dalam kehidupan sehari-hari. Dengan pendekatan tersebut, siswa lebih memiliki hasil yang komprehensif tidak hanya pada tataran kognitif (olah pikir), tetapi pada tataran afektif (olah hati, rasa dan karsa), serta psikomotor (olah raga). Lebih dari itu, dengan strategi yang tepat diharapkan dapat mengembangkan dan membentuk karakter siswa yang optimal, seperti: cerdas, berpikir terbuka, tanggung jawab dan rasa ingin tahu.

Nilai-nilai pendidikan karakter harus diintegrasikan ke dalam mata pembelajaran yang diterapkan di sekolah. Adapun nilainilai pendidikan karakter yang diterapkan di sekolah yaitu mandiri, jujur, disiplin, tanggungjawab, rendah hati, toleransi, dan adil. Pendidikan karakter bertujuan meningkatkan mutu penyelenggaraan hasil pendidikan di sekolah yang mengarah pada pencapaian pembentukan karakter dan akhlak mulia peserta didik secara utuh, terpadu, dan seimbang, sesuai dengan standar kompetensi lulusan. Melalui pendidikan karakter diharapkan peserta didik mampu secara mandiri menggunakan pengetahuannya dan menginternalisasi nilai-nilai karakter dan akhlak mulia sehingga nantinya dapat termanifestasikan dalam kehidupan sehari-hari di masyarakat. (Ovan Ardy Wiyana, 2012).

Nilai-nilai karakter yang ditanamkan terdiri atas (1) Mandiri, adapun nilai karakter kemandirian siswa adalah kepercayaan siswa terhadap kemampuan dalam membangun pembelajarannya sendiri. Sehingga memnunculkan daya inisiatif, kreatif dan keyakinan anak terhadap kemampuan pada diri siswa, menmbuhkan sikap dapat saling menerima dan menghargai diantara siswa yang satu dengan yang lain yang akan mewujudkan nilai sosial di dalam kelas. (2) Kesadaran diri. Membangun kesadaran ketika siswa dapat mengontrol kecerdasan emosionalnnya. Indikatornya adalah dengan mengontrol pengendalian diri siswa sehingga mereka bisa mengarahkan pemikiran mereka ke objek lain dan bersikap adil antar siswa. (3) Kerjasama. Nilai karakter kerjasama ini adalah kunci dalam pembelajaran konstruktif misalnya kerjasama kelompok baik di dalam kelas maupun di luar kelas Mahluk hidup membentuk kelompok dan bergabung menciptakan bentuk kehidupan yang baru yang terdiri dari beragam organisme. Kesuksesan adalah sesuatu yang dibagi bersama.Nilai karakter pendukung yang ditanamkan yaitu rasa ingin tahu, gemar melakukan, teliti, percaya diri, keberanian, religius dan peduli lingkungan.

Meskipun telah terdapat 18 nilai pembentuk karakter bangsa, namun satuan pendidikan dapat menentukan prioritas pengembangannya dengan cara melanjutkan nilai prakondisi yang diperkuat dengan nilai yang diprioritaskan dari 18 nilai di atas. Dalam implementasinya, jumlah dan jenis karakter yang dipilih tentu akan dapat berbeda antara satu daerah atau sekolah dengan yang lainnya. Hal itu tergantung pada kepentingan dan kondisi satuan pendidikan masing-masing.

Daryanto dan Suryatri (2013) menyatakan bahwa dalam mengintegrasikan pendidikan karakter ke dalam proses pembelajaran berbagai mata pelajaran hendaknya senantiasa berlandaskan pada prinsip-prinsip sebagai berikut:

a) Nilai karakter adalah bagian terintegrasi dari semua mata pelajaran dan segala kegiatan di sekolah dan di rumah.

b) Nilai karakter yaitu jujur, cerdas, kreatif, peduli, tangguh, disiplin, cinta tanah air merupakan kesatuan yang tidak dapat dipisahkan.

c) Pengalaman belajar yang baik adalah dengan cara terpadu karena dalam 
Hidayat, Tri Sukitman

hidup kita sehari-hari, kita tidak hanya memiliki dan berpegang pada satu nilai saja sepanjang hari.

d) Nilai karakter tidak hanya untuk diajarkan, tetapi harus dimunculkan dalam diri siswa sebagai sikap dan perilaku dalam keseharian hidupnya

Nilai-nilai tersebut merupakan bagian dari penilaian secara keseluruhan pada pertengahan dan akhir semester, serta akhir tahun. Artinya, dalam penilaian yang sifatnya kognitif melalui tes sumatif, juga dipertimbangkan aspek-aspek sebagaimana disebutkan di atas. Untuk mengukur tingkat keberhasilan pelaksanaan pendidikan karakter di satuan pendidikan dilakukan melalui berbagai program penilaian dengan membandingkan kondisi awal dengan pencapaian dalam waktu tertentu. Penilaian keberhasilan di Madrasah Ibtidaiyah dilakukan melaui langkah-langkah berikut:

a) Mengembangkan indikator dari nilainilai yang ditetapkan atau disepakati

b) Melakukan pencatatan terhadap pencapaian indikator

c) Melakukan analisis dan evaluasi

d) Melakukan tindak lanjut

\section{Kesimpulan}

Pelaksanaan pendidikan karakter di Madrasah Ibtidaiyah (MI) dapat dilaksanakan pada ranah pembelajaran (kegiatan pembelajaran), pengembangan budaya sekolah, kegiatan ekstrakurikuler dan kegiatan keseharian di rumah

\section{DAFTAR PUSTAKA}

A, Doni Koesoema, (2007). Pendidikan Karakter: Strategi Mendidik Anak di Zaman Global, Jakarta: Grasindo.

Agus Wibowo, (2013). Manajemen Pendidikan Karakter di Sekolah, (Pustaka Pelajar: Yogyakarta.

Ainullah, Nurla Isna. (2011). Panduan Menerapkan Pendidikan Karakter di Sekolah.Yogyakarta: DIVA Press.

Depdikbud. (2003). UU No 20 Tahun 2003 tentang Sistem Pendidikan Nasional. Jakarta: Depdikbud.

Direktorat Pendidikan Madrasah, Wawasan Pendidikan Karakter dalam Islam, Jakarta: Kemenag, 2010.

Halstead \& Taylor. (1996). Value in education and education in value. London: 64 Routledge Falmer.

Kemdiknas. (2011). Panduan pelaksanaan pendidikan karakter. Jakarta

Lickona, Thomas. (1991), Educating for Character: How Our School Can Teach Respect and Responsibility, New York

Oktarina, N., \& et all. (2015). Character Education Evaluation Model Based on School Culture for Elementary School. Journal of Research and Method Education, 05(05), 11.

Sugiyono. (2015). Metode Penelitian Kuantitatif, Kualitatif, dan R\&D. Bandung: Alfabeta. 
Tim Redaksi Tessaurus Bahasa Indonesia, (2008) Tesaurus Bahasa Indonesia Pusat Bahasa (Jakarta: Departemen Pendidikan Nasional

Wafiqni, N., \& Latip, A. E. (2015). Psikologi Perkembangan Anak Usia MI/SD: Teori dan Grand Design Pendidikan Berbasis Perkembangan. Jakarta: UIN Press. Wahyu

Wijanarko, W. (2011). Pengaruh Metode Outbond terhadap Pembentukan Karakter Kepemimpinan Siswa Sekolah Alam Indonesia. Skripsi: UIN Syarif Hidayatullah Jakarta.

Wiyani ovan Ardy. (2012), Pendidikan Karakter Berbasis Iman dan Taqwa, Yogyakarta: Teras 